\title{
Editorial: The Politics of Funding
}

\author{
WENDY HARCOURT
}

When Kléber Ghimire suggested that Development should publish a set of research articles commissioned by UNRISD on funding social movements and non-government organisation (NGOs) in the context of the global UN Conferences and the World Social Forum (WSF) I welcomed the opportunity. Development over the last years has regularly featured the engagement of civil society in the UN Conferences with many issues devoted to the paradigm shifts those meetings represented in development thinking in the 1990s. In the last years, Development has also given space to actors engaged in the WSF and civil society movements that are creating new global political spaces for social change. Interestingly, in all of that debate little attention was given to the funding and how it impacted on the agendas being debated. The UNRISD offer was both innovative and timely.

As we go to press with the assembled articles from the UNRISD project and some additions I now see that it was not so much innovative as necessary. The issue of funding NGOs and social movements is a very complex subject and takes us to the contentious subject of the politics of funding in development. As an initial step in this debate, the articles cover development project funding through NGOs, funding of UN conferences and the questions being raised about the funding process of the World Social Forum.

The first set of articles on NGOs and funding raise some important issues around what Catherine Agg calls the 'current paradigm' of aid and the role of NGOs. Almost all point to the problem of dependency on external funding and the difficulty for NGOs to hold to their own agendas while also carrying out donor led agendas. What Santiago Daroca Oller calls the 'financial aid chain' links actors from the donor agency to International NGOs to national NGOs to local community groups in institutional procedures and management structures. Such process often mean that NGOs working on the ground can spend as much time filling out bureaucratic forms and fitting their work into the required donor indicators as doing the work itself. Lisa Bornstein explicitly questions the systems of accountability set up by donor agencies based on her observations of South Africa NGOs scrambling to work to logframes. She points out how they only create 'webs of deception' as NGOs fail to report truthfully and in the end work against efficiency. Fernand Vincent in a detailed case study in Uganda shows how difficult it is to have an equal partnership when bureaucratic procedures dictate the goal and aim of any project, and when the decisions around money remain in the hands of 
just one of the partners. An important question raised in the journal is how to change the present donor arrangements of the NGO financial aid chain in order to address tensions around the effectiveness of development cooperation finance in general.

The second set of articles on the big UN Conferences look at the Global Earth Summit meeting in Rio in 1992 and prepcoms in Senegal in 1995 and Bali in 2000. They reveal how the states and big international NGOs set agendas in these huge events within which local NGOs are obliged to fit their own concerns. The funding structures favour the larger NGOs who are conversant with international agendas although some wily small NGOs do manage to make links between local concerns and international agendas - such as the Indonesian case of Turtle Eggs. However, from their analysis it seems that the majority of local NGOs are side lined from the internationally led and funded events. The article on Rio 1992 by Silvana De Paula suggests this happens to the extent that many small NGOs cannot participate at all, as was the case for many Brazilian NGOs at the Earth Summit. Fatou Sarr points out that government registration of NGOs too often determines who receives funds and therefore can participate in big international conferences, creating a self-perpetuating cycle of knowledge and access to funds and legitimacy to only a small number of NGOs. She also points out that the weak position of NGOs refunding means that their own agendas are muted in the follow-up work of the conferences. Behind these issues of diversity among NGOs is how to take up the democratic deficit - which NGOs can speak for the marginalized in these big events.

Overall, in relation to funding demands, NGOs seem to be operating as one of the weaker actors in the development business. The concept of partnership is highly questioned by the authors. NGOs clearly see current funding arrangements make it difficult for them to enter into political spaces or to pursue their own agendas, either because of lack of money or because of lack of time as they are caught up in fulfilling bureaucratic requirements. Even if, as many authors point out, it is not possible to generalize from these examples, government organisation (INGOs) and national NGOs in the North who act more as funders than NGOs, it seems that NGOs are largely operational players bound by the never ending struggle to find money and trying to fit their own concerns into larger agendas, with little political voice as a result.

As would be expected by readers of Development particularly the recent issue in volume 48 on 'Movement of Movements', the social movements linked to the WSF process take pains to separate themselves from NGOs and are sure of their political voice and the political spaces they are creating. Nevertheless, as the articles in this issue show the WSF requires a large amount of money and funding is also a contentious debate in this arena. The difficulty is not so much because social movements complain of being caught in bureaucratic structures that lead to dependency and lack of political autonomy. Rather they are concerned about where the money comes from, if they should accept it or not and how to avoid becoming trapped in massive bureaucratic power plays that make for rigid and unequal relations among the various actors engaged in managing the funding and therefore agenda setting of the WSF. The authors assessing funding and the WSF agree that there needs to be clear ethical guidelines around funding but also point out that there is no easy way to know from where the money comes beyond the obvious such as multinational companies. They also point out, particularly Ghimire and Liliana Diaz that the WSF process is an increasingly expensive process involving more and more people and cannot be self-financed therefore financial strategies are required, one mechanism being suggested by Murat Yilmaz is through fair trade.

As Stefano Prato states in his interview, it is very difficult to have discussions around funding with NGOs and social movements in anything beyond corridor talk, even if funding is at the basis of their survival. Donors are determining the direction of NGO agendas and creating critical debate among social movements. The research by UNRISD is therefore a welcome way to start opening up the debate in an informed manner. At the micro level the articles gathered in this issue show how fund- 
ing strategies for NGOs is an integral part of development. Equally, the issue shows that funding is determining how many people and who can participate in the WSF process. Yet it must be said that this handful of articles can only skim the surface of the debate around the macro agendas determining who has access to the funding, who is determining the power plays and how civil society is embedded within larger power politics.

The challenge for all of us interested in social justice is to take on that broader reality and for NGOs and social movements to make the links between their resource needs and the chain of events that links them to the big players and the global political and economic environment. The consciously brave political actors among civil society (if we can bring together for a moment NGOs and social movements in that category) must learn to speak directly. They need to work frankly with donors to decide on funding strategies not based on 'objective' assessments of success of the receivers of the funds but on a much more realistic and pragmatic agreement on how to move forward on the broad agendas demands collective effort if it is to be achieved. The AWID Fundher initiative described in Last Word is perhaps the most innovative and exciting response to the debates around funding - the needs to hold funders accountable for their decisions and for women's movements to work with them towards financing women's social, political and economic equality and rights.

Following this approach it is important to look at the political and economic environment determining donors' agendas, and therefore to look at how to create the space to negotiate more equally resource allocation, monitoring and political strategies required to make the money work for long term and sustainable economic and social justice. As Prato points out it is as if donor rules are in contradiction to all the lessons we have collectively learned about thinking holistically and long term. NGOs and social movements need find ways to work with donors to create shared political spaces and no doubt will transform economic and social institutional relations in doing so. We have to address in this transformation the existence of corruption, the need for accountability as well as the harsh reality of competition for funds.

As I was completing the editing for this issue of the journal, we had the first ever associate editors meeting in London, and the chance to debate the directions of Development as we come up to the 50th anniversary issue. Our debate around the title and the messages we wanted this edition of the journal to convey suggest that Development has a role to play in opening up the debate around power and money issues in development and the global struggle towards social transformation. Recognizing the importance of these concerns, and the rarity with which they are discussed, the editorial team have agreed to continue the debates in future issues of the journal spreading the net wider to look at financing for development as a whole as well as the macro picture within which we are all operating.

I would like to thank UNRISD and Kléber Ghimire for their collaboration and look forward to readers' responses to the articles assembled in this issue of Development and to our on-going discussion in future issues on the politics of funding. 